\title{
THE ROLE OF FISCAL POLICY IN THE CRISIS: A LITERATURE REVIEW
}

\author{
Windraty Ariane Siallagan \\ The Ministry of Finance, Republic of Indonesia \\ Gd. Djuanda I, Jl. Dr. Wahidin Raya No. 1, Jakarta Pusat, DKI Jakarta, 10710, Indonesia \\ Correspondence Email: abigailariane@gmail.com
}

Submitted: 20-09-2020, Reviewed:11-10-2020, Published: 31-10-2020

\begin{abstract}
Global crisis due to Corona Virus Disease (COVID) 19 pandemic motivates research concerning the role of fiscal policy in the crisis. Lessons learned on success dan failed factor of fiscal in responding crisis is of greater importance. This research employs review literature to identify the current status of literature on the role of fiscal in crisis. The research aims to review previous research, mainly literature on a fiscal policy designed during an economic recession or crisis. Lessons from the past crisis and the extent to which fiscal policy has roles in overcoming crisis are evaluated through literature. By investigating and analyzing 29 academic works of literature, this research finds that fiscal stimulus and austerity measures are two government options in a crisis. When the fiscal stimulus is launched, the deficit becomes the following consequence, usually funded by debt. This research also shows a plethora of studies on the fiscal role in developed countries such as Europe, but only a meager of research conducted in Asia, particularly South-Eastern Asia. The finding encourages research on the extension of fiscal role themes in crisis and mixed-method employment to render new insights into the subject matter.
\end{abstract}

Keywords: Fiscal Stimulus, Economic Crisis, Deficit, Debt

\begin{abstract}
ABSTRAK
Krisis ekonomi global yang terjadi saat ini akibat pandemi Corona Virus Disease (COVID) 19 memotivasi penelitian terkait peran kebijakan fiskal dalam krisis. Pembelajaran mengenai kesuksesan dan kegagalan kebijakan fiskal utamanya dalam pemberian stimulus fiskal dalam menangani krisis semakin meningkat. Penelitian ini bertujuan untuk mereview penelitian terdahulu, utamanya literatur terkait kebijakan fiskal yang diambil dalam kondisi resesi atau krisis ekonomi. Pembelajaran dari krisis yang pernah terjadi selama ini dan sejauh mana kebijakan fiskal berperan dalam mengatasi krisis dievaluasi melalui literatur. Dengan melakukan investigasi dan analisis terhadap 29 literatur ilmiah, penelitian ini menemukan bahwa stimulus fiskal dan kebijakan penghematan adalah dua pilihan kebijakan yang kerap diambil pemerintah dalam dalam kondisi krisis. Dalam konteks kebijakan yang diambil adalah kebijakan ekspansif atau stimulus fiskal, pelebaran defisit adalah konsekuensi yang mengikuti, yang biasanya dibiayai dari utang. Penelitian ini juga menunjukkan studi peran fiskal dalam krisis banyak dilakukan di negara-negara maju yang cukup banyak di negara-negara Eropa, namun relatif terbatas di negara Asia khususnya Asia Tenggara. Implikasi penelitian ini adalah perlunya upaya untuk mendorong adanya perluasan tema penelitian terkait peran fiskal dan utilisasi metodologi campuran yang memberikan pemahaman baru dalam tema penelitian.
\end{abstract}

Kata kunci: Stimulus, Fiskal, Krisis, Ekonomi, Defisit, Utang

\section{BACKGROUND}

This research is a review of the literature on fiscal policy in the crisis. In the last few decades, the national and global economies have experienced frequent crises. Obstfeld et al. (2012) describe the banking /financial crises in the world at least in certain periods, in 1890-91, 1907-08, 1913-14, 1931-32, 2007-2008. The 2007/2008 global crisis is a crisis that has 
Vol.6, No.2, 2020

Doi: https://doi.org/10.24198/cosmogov.v6i2.29509

http://jurnal.unpad.ac.id/cosmogov/index

been widely researched by global economic experts (Hur \& Park, 2018).

The global crisis in 2008 that originated in the US mortgage market used a good number of financial instruments to overcome it. Romer (2012) states that since 2008, the world economy has experienced at least three types of crises: the financial crisis, the unemployment crisis, and the interrelated fiscal crisis.

This research was conducted when the world experienced an unprecedented crisis due to the COVID-19 pandemic in 2020. Many countries launched fiscal stimulus to reduce the impact of the crisis on the economy. As with previous crises, in the context of the COVID-19 pandemic that has been experienced by 215 economic jurisdictions, fiscal policy is often relied on to boost the economy and avoid the risk of entering into a deeper recession. Understanding how fiscal policy is used as an instrument for crisis management is becoming increasingly important.

The role of fiscal policy in an economic recession is a means of economic stabilization. For this reason, lessons learned from past crises need to be explored as lessons learned in reducing the current crisis.

Literature review related to fiscal policy in crisis aims to: (1) obtain lessonslearned from the crisis that can be used as insight for current and future policies; (2) identify the gap in the literature related to research on the role of fiscal policy in overcoming the crisis; and (3) provide recommendation for future studies or research. This research fills the gap in the current Indonesian literature on how fiscal policy was made during the crisis, particularly the current COVID-19 crisis. Lessons learned are expected to guide future research on the role of fiscal policy in stabilizing the economy.

To guide research systematically, this study develops a concept map based on fiscal theory/concepts and provides a relationship or linkage between the concept with other economic variables. The concept map is useful for determining key concepts or keywords for literature search and analysis related to research topics (Rowley \& Slack, 2004).

As stated in various literature, during a recession, the government will experience a decrease in income to increase spending. To find funds to overcome the deficit, the government uses three instruments, namely taxes, printing money, and public debt, with a preference for using debt because it is efficient in an emergency context (Përmeti, 2017). This point illustrates that the fiscal deficit is often dissolved with other fiscal instruments, namely debt.

Experiences in Indonesia and various countries show that in a crisis, the intervention that is often used by the Government is fiscal policy. Simorangkir \& Adamanti's research (2010) found that in dealing with the 2008 crisis, the Indonesian government took a fiscal expansion combination by providing fiscal stimulus and monetary policy by cutting the interest rate, boosting the Indonesian economy effectively.

The ongoing COVID-19 pandemic has led to the recession, and until this research was finalized, the Indonesian government has launched a fiscal stimulus 
Vol.6, No.2, 2020

Doi: https://doi.org/10.24198/cosmogov.v6i2.29509

http://jurnal.unpad.ac.id/cosmogov/index

that amounted to around 4,2\% GDP (Kementerian Keuangan, 2020). The fiscal stimulus has caused the government to raise the deficit level in 2020, from the beginning of the year around $1.76 \%$ to $6.34 \%$ as stipulated in Presidential Regulation No. 72 of 2020 concerning Amendments to Presidential Regulation Number 54 of 2020 concerning Changes in Posture and Details of the State Budget for Fiscal Year 2020. The deficit is financed by a source of debt, which results in an increase in public debt in Indonesia.

As depicted in Figure 1, the concept map describes the financial/economic crisis that needs to be intervened with fiscal policies, the main variables of which are income (mainly taxes) and expenditures. In the context of a deficit, financing is carried out through debt as a fiscal instrument.

\section{Figure 1 Concept Map of the Role of Fiscal Policy in Crisis}

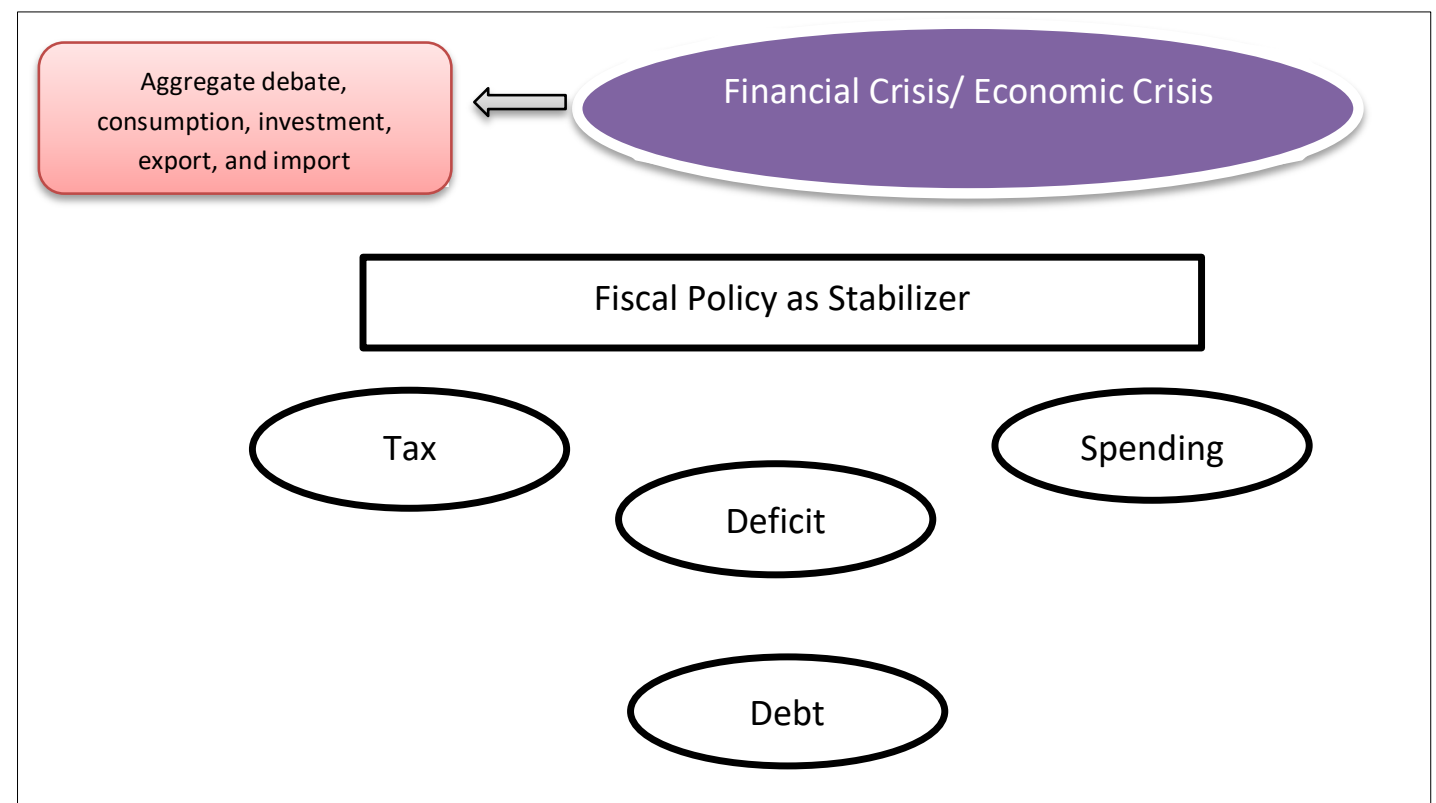

Source: Author

\section{RESEARCH METHOD}

This study uses a bibliographic approach or a literature review. Ramdhani et al. (2014) state that a literature review provides published information about a particular topic and sometimes a topic within a certain time period. The literature review in this study reflects the role of policy in the crisis by exploring literature from 2002-2020.
The data collection method is literature search using a search engine through the electronic database of the National Library of Indonesia PNRI and databases publisher such as utilizing Ebsco Host, Emerald Insight, and Proquest and using search engines such as Google and Google Scholar. 
Vol.6, No.2, 2020

Doi: https://doi.org/10.24198/cosmogov.v6i2.29509

http://jurnal.unpad.ac.id/cosmogov/index

The unit of analysis in this study is as illustrated in table 1 below:

Table 1. Unit of Analysis

\begin{tabular}{l|r|r}
\hline \multicolumn{1}{c|}{ Type of Literature } & Amount & Year \\
\hline Scientific Paper & 16 & $2002-2018$ \\
\hline $\begin{array}{l}\text { Academic Journals (discussion paper, a working paper from } \\
\text { international institutions such as the IMF, World Bank, } \\
\text { European Central Bank, and ADB }\end{array}$ & 12 & $2009-2020$ \\
\hline Book & & \\
\hline Amount & 1 & 2012 \\
\hline
\end{tabular}

In order to avoid bias, this study used a literature review protocol. The protocol includes research phases starting with: (1) developing a concept map that guides the literature search; (2) analyzing and synthesizing the literature by exploring the similarities and differences (compare and contrast) of the existing studies in the literature; (4) identifying gaps in the literature and obtaining learning points from past economic crises and recession. Besides, this study provides directors or directions that can be the basis for future research. Recommendations for future research directions or directors are the main elements of the literature review.

As far as possible, reference sources are primary sources in the form of journals / scientific articles, books, and similar research articles published by international institutions (working papers, discussion.
Papers, or conference papers), which are listed in Table 2. 
Vol.6, No.2, 2020

Doi: https://doi.org/10.24198/cosmogov.v6i2.29509

http:/jurnal.unpad.ac.id/cosmogov/index

Tabel 2. Literature on fiscal stimulus in crisis

\begin{tabular}{|c|c|c|c|}
\hline Discussion Theme & Methodology & Year & Reference \\
\hline $\begin{array}{l}\text { Influence of Crisis in the } \\
\text { Economy }\end{array}$ & $\begin{array}{l}\text { Qualitative } \\
\text { Qualitative } \\
\text { Qualitative } \\
\text { Qualitative } \\
\text { Quantitative } \\
\text { Quantitative }\end{array}$ & $\begin{array}{l}2009 \\
2012 \\
2012 \\
2014 \\
2015 \\
2018\end{array}$ & $\begin{array}{l}\text { Freedman et al., } \\
\text { (2009) } \\
\text { Obstfeld et al. (2012) } \\
\text { Romer (2012) } \\
\text { Doraisami (2014) } \\
\text { Das (2015) } \\
\text { Hur and Park (2018) }\end{array}$ \\
\hline $\begin{array}{l}\text { Position Fiscal When crisis } \\
\text { (expansive and contractive) }\end{array}$ & $\begin{array}{l}\text { Quantitative } \\
\text { Kuantiatif } \\
\text { Qualitative } \\
\text { Quantitative } \\
\text { Qualitative } \\
\text { Quantitative } \\
\text { Quantitative } \\
\text { Quantitative } \\
\text { Quantitative }\end{array}$ & $\begin{array}{l}2006 \\
2009 \\
2009 \\
2012 \\
2012 \\
2015 \\
2017 \\
2018 \\
2018\end{array}$ & $\begin{array}{l}\text { Lee et al. (2006) } \\
\text { Freedman et al. (2009) } \\
\text { Brondolo (2009) } \\
\text { Obstfeld et al. (2012) } \\
\text { Romer (2012) } \\
\text { Blömer et al. (2015) } \\
\text { Socol \& Feraru (2017) } \\
\text { Hur and Park, (2018) } \\
\text { Beckman (2018) }\end{array}$ \\
\hline Fiscal Stimulus in crisis & $\begin{array}{l}\text { Quantitative } \\
\text { Quantitative } \\
\text { Qualitative } \\
\text { Qualitative } \\
\text { Qualitative } \\
\text { Qualitative } \\
\\
\text { Qualitative } \\
\text { Quantitative } \\
\text { Theoretical } \\
\text { Theoretical } \\
\text { Quantitative } \\
\text { Quantitative } \\
\text { Quantitative } \\
\text { Quantitative } \\
\text { Quantitative } \\
\text { Qualitative } \\
\text { Theoretical }\end{array}$ & $\begin{array}{l}2002 \\
2008 \\
2009 \\
2009 \\
2009 \\
2011 \\
2012 \\
2013 \\
2013 \\
2014 \\
2015 \\
2018 \\
2018 \\
2019 \\
2019\end{array}$ & $\begin{array}{l}\text { Blanchard \& Perotti, } 2002 \\
\text { Romer \& Romer, } 2008 \\
\text { Freedman et al., } 2009 \\
\text { Gravelle } \text { et al., } 2009 \\
\text { Padoan, 2009 } \\
\text { Kaplanoglous \& Rapanos, } \\
2011 \\
\text { Romer, } 2012 \\
\text { Radula, 2013 } \\
\text { Marglin \& Spiegler, } 2013 \\
\text { Mencinger \& Aristovnik, } \\
\text { 2014 } \\
\text { Ban, 2015 } \\
\text { Hur \& Park, } 2018 \\
\text { Beckman, } 2018 \\
\text { Holland, } 2019 \\
\text { Stupak, } 2019\end{array}$ \\
\hline
\end{tabular}


Vol.6, No.2, 2020

Doi: https://doi.org/10.24198/cosmogov.v6i2.29509 http://jurnal.unpad.ac.id/cosmogov/index

\begin{tabular}{|c|c|c|c|}
\hline $\begin{array}{l}\text { Multiplier Effect fiscal crisis of } \\
\text { the Fiscal Policy in }\end{array}$ & $\begin{array}{l}\text { Qualitative } \\
\text { Theoretical } \\
\text { Theoretical } \\
\text { Qualitative } \\
\text { Qualitative } \\
\text { Quantitative } \\
\text { Theoretical }\end{array}$ & $\begin{array}{l}2009 \\
2009 \\
2013 \\
2014 \\
2009 \\
2017 \\
\\
2019\end{array}$ & $\begin{array}{l}\text { Gravelle et al., } 200 \\
\text { Stupak, } 2019 \\
\text { Marglin \& Spiegler, } 2013 \\
\text { Doraisami, } 2014 \\
\text { Padoan, 2009 } \\
\text { Deskar-Škrbić \& Šimović, } \\
2017 \\
\text { Stupak, } 2019\end{array}$ \\
\hline Fiscal Deficits & $\begin{array}{l}\text { Qualitative } \\
\text { Quantitative } \\
\text { Quantitative } \\
\text { \& Qualitative }\end{array}$ & $\begin{array}{l}2011 \\
2018 \\
2019\end{array}$ & $\begin{array}{l}\text { Kaplanoglous \& Rapanos, } \\
2011 \\
\text { Hur \& Park, } 2018 \\
\text { van Riet, } 2019\end{array}$ \\
\hline Public Debt & $\begin{array}{l}\text { Quantitative } \\
\text { Qualitative } \\
\text { Qualitative } \\
\text { Quantitative }\end{array}$ & $\begin{array}{l}2016 \\
2017 \\
2019 \\
2020\end{array}$ & $\begin{array}{l}\text { Bal \& Rath (2016) } \\
\text { Përmeti (2017) } \\
\text { Essl, et al., 2019) } \\
\text { (Koh et al., 2020) }\end{array}$ \\
\hline Other themes & $\begin{array}{l}\text { Qualitative } \\
\text { Qualitative }\end{array}$ & $\begin{array}{l}2011 \\
2015\end{array}$ & $\begin{array}{l}\text { (Peters et al., 2011) } \\
\text { (Das, 2015) }\end{array}$ \\
\hline
\end{tabular}

\section{RESULTS AND DISCUSSION}

This study found a common thread in 29 of the literature, which can be clustered into (1) main topics of literature discussion, (2) literature coverage; and (3) methodology.

\section{Main topics of discussion}

This study found that the main topics of discussion in the literature can be grouped into 6 main themes, namely: a) The Effect of Crisis on the Economy; (b) Fiscal Position; (c) Fiscal Stimulus in Crisis; (d) Fiscal Multiplier Effect; (e) Fiscal Deficit; (f) Public Debt; (g) Other themes.

\section{The Effect of the Crisis on the Economy}

The effect of a crisis or recession on the economy is confirmed both in macroeconomic and empirical theory. The literature shows similar variables when describing the effects of the crisis on the economy, reflecting mainly in the sharp decline in aggregate demand and output due to a loss of confidence (Hur \& Park, 2018; Freedman et al., 2009).

Stupak (2019) states that aggregate demand in the economy falls during a recession, which results in slower wage growth, a reduction in the workforce, lower business income, and lower investment. Stupak's (2019) argument supports previous research conducted by Das (2015) that the effect of a crisis or recession is usually reflected in a decrease in the international trade volume, credit, investment, assistance, and even austerity policies carried out by various countries. This is also in line with 
Vol.6, No.2, 2020

Doi: https://doi.org/10.24198/cosmogov.v6i2.29509

http://jurnal.unpad.ac.id/cosmogov/index

Doraisami (2014), who emphasizes that the impact of the crisis on the economy is often reflected in a decline in exports, lower commodity prices, and a decline in foreign direct investment (FDI).

Obstfeld et al. (2012) describe how the influence of the subprime mortgage crisis in the United States ended in the global panic and a sharp decline in international trade that resulted in a recession. According to them, the impact of the crisis impacted the availability of credit or loans and the level of confidence, resulting in a sharp increase in the country's unemployment rate.

Literature essentially illustrates that the crisis brought about a general decline in the economic performance as reflected in the indicators of the main economic variables such as output and aggregate demand, namely deteriorating consumption, investment, exports, and imports.

\section{Fiscal Stance}

Fiscal position or stance in crisis has been elaborated in the research on fiscal policy during a recession. The results of this literature review show that in crisis conditions, there are two fiscal positions supported by the economists and carried out by various countries, namely fiscal stimulus/ expansionary fiscal policy and austerity measures /contractive fiscal policy (Marglin \& Spiegler, 2013).

The conventional fiscal stimulus policy is the dominant response in various parts of the world in economic recovery after the crisis (Hur \& Park, 2018). This has been previously confirmed by Obstfeld et al. (2012), who argued that there is a tendency for countries experiencing a crisis to apply a larger fiscal stimulus package. Stupak (2019) put forward a similar argument that the Government can use fiscal stimulus to stimulate economic activity by increasing spending, reducing tax revenues, or combining both. Historically, the government has followed a pattern of increasing fiscal stimulus during recessions.

However, not all countries undertake what is called expansionary fiscal during times of crisis. Estonia, for example, when dealing with the crisis in 2009, did not take a fiscal stimulus policy but a policy that combined savings and increased taxes (Raudla, 2013). Research conducted by Mencinger \& Aristovnik (2014) regarding the impact of the economic crisis in 16 European countries also found that the fiscal position was more expansionary before the crisis than after the 2008 crisis. Their research shows that during the crisis, policies taken were more on contractionary fiscal policies or policies - savings in the European Union.

Beckman's research (2018) provides an interesting result: the fiscal position in response to a recession sometimes changes direction. Countries that during the crisis launched contractionary fiscal policies by making savings often turned towards expansionary policies. Beckman (2018) examines that tendency to reverse direction is closely related to the dependence of a country's economy on other countries and the fiscal literature that often ignores international influences on fiscal policy. These countries' fiscal policies tend to be similar to the fiscal policies taken by their trading partners, especially regarding exports and imports. Expansive fiscal policy 
Vol.6, No.2, 2020

Doi: https://doi.org/10.24198/cosmogov.v6i2.29509

http://jurnal.unpad.ac.id/cosmogov/index

tends to increase demand for imports, while contractive fiscal policy tends to increase import policy.

Ban (2015) argues that nearly all policymakers in Europe carry the austerity measures (austerity) during the crisis deemed necessary to reduce debt, but may encourage growth. Meanwhile, according to Ban (2015), the IMF supports fiscal stimulus policymaking during crisis conditions, although the IMF's position on this has changed from time to time.

Holland (2019) underlines that the fiscal position fluctuates between fiscal expansion and austerity and the assessment of their effectiveness is not yet clear. On the other hand, the austerity policy was criticized and is considered ineffective in times of crisis. For example, Das (2015) states that austerity policies have bad consequences for vulnerable people.

The study conducted by Mencinger \& Aristovnik (2014) also provides another insight into which more fiscal positions are pro-cyclical taken both before and at the beginning of the crisis, reflecting the inconsistency of policies taken with economic theory. This supports Socol \& Feraru's (2017) research regarding the procyclical nature of the fiscal policies taken by Central and Eastern European countries at times of crisis. This research contradicts the economic theory, which states that the policies taken are counter-cyclical and not pro-cyclical during a crisis.

This literature review shows that whatever fiscal position is taken, there are implications for fiscal and economic conditions in the future. Romer (2012) identifies several implications of the fiscal position, namely: (1) fiscal tightening suddenly tends to be unproductive; (2) fiscal tightening, if implemented, needs to be implemented gradually; and (3) strong countries have to implement expansionary policies, (4) structural reforms are needed in times of crisis even though the impact is long-term; and (5) monetary policy must be more supportive.

\section{Fiscal Stimulus in Crisis}

If the fiscal position varies in response to economic conditions, studies show that fiscal stimulus is a common macroeconomic response during a crisis because it is considered effective in overcoming a crisis. Even the International Monetary Fund (IMF) calls on countries to launch a global fiscal stimulus in handling the 2008 crisis (Freedman et al., 2009).

Studies in Thailand, Malaysia, and Indonesia show that the global crisis's macroeconomic response is a fiscal stimulus package. There are profound differences in size and composition and fiscal stimulus and challenges (Doraisami, 2014). In particular, Blanchard \& Perroti (2002) underlined that the fiscal stimulus of 1 percent of GDP had been found to increase GDP by almost 1 percent by as much as 2 to 3 percent of GDP when the stimulus effect is at its peak in the following years.

Freedman et al. (2009) state the dangers of a large-scale fiscal stimulus package coupled with a lack of fiscal discipline. In this context, they emphasized possible solutions such as long-term fiscal discipline, adopting a medium-term fiscal framework, and introducing fiscal rules that 
Vol.6, No.2, 2020

Doi: https://doi.org/10.24198/cosmogov.v6i2.29509

http://jurnal.unpad.ac.id/cosmogov/index

articulate long-term targets for the ratio of the fiscal deficit to GDP.

Lee et al. (2006) examine the fiscal position during the Korean crisis and found that expansionary fiscal was a policy taken during Korea's crisis. The deficit was widened after the crisis. Their research provides evidence that although the expansionary fiscal policy has succeeded in stimulating the economy and facilitating the government bond market development, there is still a negative effect as debt has risen sharply after the financial crisis. Besides, increasing government guarantees and contingent obligations ignore fiscal transparency and efficiency of fiscal policy.

In essence, fiscal stimulus consists of spending stimulus and income or tax stimulus. Various literature discusses the effect of fiscal stimuli both on spending and taxes on the economy and finds that the impact of spending stimulus is better than the impact of tax stimulus in a crisis (see Romer, 2012; Kaplanoglou \& Rapanos, 2011; Blanchard and Perotti, 2002; Freedman et al., 2009; Gravelle et al., 2009). Përmeti (2017) provides recommendations related to an increase in stimulus in spending. According to him, the increase in spending originating from debt needs to be directed at priority fields and sectors that can reduce public debt's negative impact on economic growth.

If there is relatively more literature regarding the spending stimulus (see Freedman et al., 2009; Hur \& Park, 2018), the focus specifically on tax stimulus is relatively limited. Padoan (2009) states that even in normal times, tax cuts have a limited household consumption impact. The research is supported by Hur \& Park (2018) in an empirical analysis which shows limited evidence regarding fiscal effectiveness in Asia where they find that tax cuts tend not to affect output, whereas higher government spending has a positive impact in the Asian region at the time. The 2008-2009 crisis. According to them, fiscal expansion in Asia through higher government spending impacts economic recovery in the region.

Brondolo (2009) explains how the 2008 crisis resulted in a decrease in government income ratio relative to GDP in various countries and outlines challenges related to taxation, especially tax administration in the midst of spending cuts due to the crisis. Brondolo (2009), in his research related to tax administration, suggests strategies to improve tax compliance by providing guidance for taxpayers, shifting focus to the highest income risk, introducing legislative reforms that facilitate administration, and improve communication programs. Brondolo's research (2009) is in line with Përmeti (2017), which concludes studies related to debt in Albania, that avoiding tax evasion in the informal economy and corruption will reduce deficits and debt.

If the size or magnitude of the fiscal multiplier effect has become a consensus in the literature, the factors for the fiscal stimulus's success are also widely discussed in the research. Freedman et al. (2009) state that the prerequisite for a successful fiscal stimulus is that the stimulus referred to does not override fiscal policy's medium-term sustainability. In fact, they argue that a commitment to long-term fiscal discipline is 
Vol.6, No.2, 2020

Doi: https://doi.org/10.24198/cosmogov.v6i2.29509

http://jurnal.unpad.ac.id/cosmogov/index

necessary to avoid long-term interest rate increases, which tend to negate the effect of the GDP stimulus due to fiscal action.

A common thread in the literature regarding the role of fiscal in overcoming crises in stimulus or expansion of spending is evident. However, various literature also emphasizes that the fiscal multiplier effect is short-term (Freedman et al., 2009; Beckman, 2018). In Korea, in a study of the fiscal role of the crisis, it was found that the new estimated budget deficit was significantly larger than the official figure, especially during the crisis, which was more due to the massive issuance of governmentguaranteed bonds (Freedman et al., 2009).

Stupak (2019) argues that even in the long run, there are negative effects of fiscal policy that can be manifested due to persistent (continuous) budget deficits, persistent fiscal stimuli, and large public debt.

\section{Fiscal Multiplier}

Fiscal multiplier effect or multiplier effect has been fiscal policy objectives of any government regardless of which fiscal position is taken. This is because the effectiveness of the government's fiscal response (both stimulus and savings) depends on the value of the multiplier effect produced (Marglin \& Spiegler, 2013). The fiscal multiplier effect is generally defined as the effect of fiscal instruments' changes on real GDP (Freedman et al., 2009). This definition is supported by Stupak (2019), which states that the evaluation of the impact of fiscal stimulus on the economy is measured through the fiscal multiplier effect by economists.
The literature on the economy and economic crisis examines the different fiscal multiplier effects in different contexts (see Holland, 2019; Das, 2015). Stupak (2019) explains that the fiscal multiplier effect that is greater than one means that for every dollar the government spends, the economy grows more than one dollar. The multiplier effect could be greater than one if the initial stimulus boosts private sector spending.

Padoan (2019) argues that significant variations occur between countries regarding the size and composition of fiscal stimulus, reflecting different preferences. The main determinant of the effect of a macroeconomics stimulus is its size (Gravelle et al., 2009). Besides, the size of the fiscal stimulus and the consequences of debt accumulation will be a challenge in various countries' fiscal sustainability (Padoan, 2009).

If, in general, the literature led to the finding that there is a multiplier effect of fiscal stimulus during the crisis, the literature also shows that the size of the multiplier effect was very different and very dependent on a variety of critical factors confirmed by several researchers such as Freedman et al., (2009); Holland (2019) and Deskar-Škrbić \& Šimović (2017). Holland (2019) emphasizes issues such as trade openness, exchange rate regime, fiscal instruments (whether based on spending or taxes), debt level, monetary policy position, and whether the economy is expanding or contracting (Holland, 2019). This confirms the research of Deskar-Škrbić and Šimović (2017), which found how economic structural characteristics such as trade openness, exchange rate regime, and public debt levels 
Vol.6, No.2, 2020

Doi: https://doi.org/10.24198/cosmogov.v6i2.29509

http://jurnal.unpad.ac.id/cosmogov/index

also determine the size of the fiscal multiplier effect. High economic openness reduces the impact of fiscal spending through the effect of import outflows. A flexible exchange rate has lower fiscal spending effectiveness because the fiscal effect is limited by international trade. Meanwhile, countries with high debt levels have a low fiscal stimulus impact because additional fiscal expansion can increase risk and reduce the level of confidence in the private sector and decrease consumption and investment. Beckman (2018) argues that fiscal policy has a strong international influence because of its relation to demand imports and exports.

However, there has been debate about the effects of fiscal on the economy, primarily since the 2008 crisis (Holland, 2019; Hur \& Park, 2018). Studies on the use of fiscal stimulus to increase aggregate demand are still a matter of debate in Asia, especially regarding the effectiveness of counter-cyclical fiscal policies in the region (Hur \& Park, 2018). Using panel data crosscountry, they tested the argument regarding the role of finance in the economy. They found that the stimulus had a limited but positive impact on expanding Asian output during the global crisis.

In essence, this literature study shows that economists do not reach a consensus on the effectiveness of fiscal stimulus as an instrument for stabilizing output. Various factors are identified as determining whether the fiscal stimulus is effective or not, such as the size of the stimulus, effectiveness through the multiplier effect, which is also determined by contexts such as trade openness, exchange rate regime, and public level debt. The absence of convergence in the literature indicates that there is still a gap in the literature that needs to be followed up with research. Future research can provide new insights into what conditions and assumptions need to be met for an effective policy.

\section{Fiscal Deficit}

Studies on the economic crisis are often associated with fiscal deficits caused by fiscal expansion or fiscal stimulus (van Riet, 2019; Romer, 2012; Kaplanoglous \& Rapanos, 2011). Studies show that since 2007 after the global financial crisis, the deficit in low-income countries has widened (Essl et al., 2019).

Kaplanoglous \& Rapanos's (2011) research shows how the deficit in Greece is closely related to the government's inability to control spending and collect revenue, reflecting the weak institutional framework of tax budgeting and administration.

The normally controlled fiscal deficit will increase after the global financial crisis to maintain domestic demand in a weakening economy (van Riet, 2010).

Romer (2012) finds that long-term budget deficits will ultimately make things worse. Furthermore, Romer (2012) emphasizes that large and continuous budget deficits financed by inflows of capital can create unbalanced growth and an asset price bubble.

\section{Public Debt in Crisis}

Public debt, in general, is always related to crises, wherein various studies, it is proven that public debt tends to increase if 
Vol.6, No.2, 2020

Doi: https://doi.org/10.24198/cosmogov.v6i2.29509

http:/jurnal.unpad.ac.id/cosmogov/index

there is a widening deficit (Essl, et al., 2019; Koh et al., 2020; Kaplanoglous \& Rapanos, 2011; Përmeti (2017). However, the crisis's impact is mainly experienced by developing countries with relatively high levels of debt (Përmeti, 2017; Essl et al., 2019).

Kaplanoglous \& Rapanos (2011) describe Greece, which has a large debt due to a long-term fiscal deficit. However, there is also empirical evidence that an increase in debt is not positively related to an increase in the deficit, such as a study conducted by Bal $\&$ Rath (2016) in India, which proved that in the period 1970-2013 India there was no correlation. between debt and deficit

Regarding the effect of debt on the economy, this study finds. There is no consensus in the literature. Some support the opinion that debt has a positive influence on the economy, primarily by Keynesian economic supporters who state that debt is neither a burden nor profitable; however, it can exploit idle resources and thereby increase national income (Bal \& Rath, 2016). According to Përmeti (2017), debt can drive aggregate demand and economic growth in the short term, but in the long term, debt will affect the reduction of capital and state income. For this reason, debt policy needs to pay attention to matters such as determining the optimal debt portfolio and assessing and evaluating debt.

Conversely, other studies provide evidence of the negative effect of debt on the economy, as evidenced by Koh et al. (2020), Romer (2012), and Përmeti (2017).

Koh et al. (2020) emphasize the negative effect of debt on the economy. Koh et al. (2020) conclude that a rapidly increasing debt will increase the likelihood of a fiscal crisis. The experiences of financial crises usually use a combination of fiscal, monetary, and financial that is not sustainable and usually experiences structural and institutional weaknesses. Their research is supported by a study in Albania by Përmeti (2017), which shows a negative effect of public debt on economic growth. However, limited economic growth has increased the budget deficit and debt at the same time. The study confirms the optimal debt portfolio and an assessment of current debt and the effects of debt on other indicators.

Romer (2012) also provides evidence that public debt can harm the economy even if foreign capital inflows suppress interest rates. Essl et al. (2019) found evidence that there was an increase in the mean (median) value of government debt, which absorbed income due to interest payments. The increase in expense due to interest reflects the vulnerability of lowincome countries to debt. If it is not managed properly, debt will only have a negative impact.

The literature shows that debt has both positive and negative effects, depending on the context in which it is executed. The lesson from this is how debt can be managed properly by paying attention to the existing context.

\section{Other themes}

If discussions of spending, income dominate research on the effects of fiscal on the crisis, and deficits, and public debt, literature discusses the effects of the crisis on public sector governance and management (such as Peters et al., 2011). Peters et al.'s 
Vol.6, No.2, 2020

Doi: https://doi.org/10.24198/cosmogov.v6i2.29509

http://jurnal.unpad.ac.id/cosmogov/index

article (2011) titled "Global Financial Crisis, Public Administration and Governance" analyzes the global financial crisis to governance. Peters et al. (2011) proved that financial crises and the like resulted in varied responses in various countries, and there was no common or general response. They did not find any new paradigms in public administration and governance that emerged due to the crisis, even though during the crisis, there were innovations in economic policy.

Another study was conducted by Das (2015), who analyzed the problem of the impact of the global crisis on the informal economy with a specific focus on labor issues and decent work, fiscal consolidation, and especially savings in times of crisis, which had many negative consequences for the informal economy.

These studies show that the crisis's effect is not only on macroeconomic and fiscal variables and how to find effective fiscal policies to fix them. Research related to the crisis also proved that administration, governance, and other economic sectors were also affected by the crisis.

This literature review recommends that the study of fiscal policy in a crisis is not only related to spending and income but can be more related to other limited themes. If another theme in this study's findings is the effect of the crisis on public sector management and employment, then there is room to research fiscal policy in a crisis and its impact on human resources (government employees), policy quality, and other public management issues.

\section{Literature Coverage}

\section{Based on the Jurisdiction}

The literature that discusses fiscal stimulus during the crisis is in Europe, such as Eastern and Central Europe (Socol \& Feraru, 2017), Albania (Përmeti, 2017), Germany (Blömer et al., 2015), Yugoslavia, Croatia, and Serbia (Deskar \& Šimović, 2017). The research in Asia was carried out in India (Bal \& Rath, 2016; Das, 2015), Malaysia, India, and Thailand (Doraisami, 2014), and Korea (Lee et al., 2006).

Research related to the crisis in Germany conducted by Blömer et al. (2015) is quite interesting where the severe crisis that hit the German export manufacturing industry is very different from various countries in Europe, where the country's finances were only slightly affected. There were not many policy reforms that needed to be carried out.

This study shows that in developed countries, the impact of the crisis on state finances will differ from the conditions in developing countries, especially countries with high levels of public debt. This research found that the study of fiscal policy in overcoming crises in developing countries was quite limited, relative to developed countries.

\section{Focus of Literature}

A good number of pieces of literature on the role of fiscal in crises focuses on empirical research such as Hur \& Park (2018), Socol \& Feraru (2017), Bal \& Rath (2016), Doraisami (2014), and Zsolt (2009). There is also conceptual and theoretical literature, such as Stupak (2019) and Marglin \& Spiegler (2013). 
Vol.6, No.2, 2020

Doi: https://doi.org/10.24198/cosmogov.v6i2.29509

http://jurnal.unpad.ac.id/cosmogov/index

This literature review finds that the fiscal policy literature on crises is more elaborate on or focused on the 2008/2009 crisis, commonly referred to as the Global Financial Crisis. This is quite reasonable because the 2008/2009 economic crisis was quite severe compared to the previous year's crisis. As for the 29 literature studied, there is no research on the economic crisis related to the new COVID-19 pandemic, and of course, it can be the focus of studies in the future.

\section{Methodology}

In general, fiscal studies on crises use two approaches, both quantitative and mixed approaches. For example, a qualitative approach is used by Doraisami (2014), Romer (2012), Kaplanoglous \& Rapanos (2011), Freedman et al. (2009), and Padoan (2009). As for quantitative approaches, such as modern structural simulation was used by Lee et al. (2006), econometrics by Socol \& Feraru (2017) and Beckman (2018), while statistics by Hur \& Park (2018). The mixed approach is carried out by van Riet (2019).

Both quantitative and qualitative approaches have their advantages and disadvantages. A qualitative approach can explore a deeper context that quantitative research cannot answer and vice versa. This literature review finds that there were relatively few mixed approaches. In the future, research using mixed methodology is needed to enrich the results of the research.

\section{CONCLUSION}

The authorities in various countries take different fiscal positions during the crisis, divided into a fiscal stimulus or austerity measures. A series of research related to fiscal policy's role in a crisis leads to a common thread that fiscal stimulus is useful for increasing household and business resilience. However, the fiscal stimulus's size and composition affect the extent of its impact on the national economy.

The widening of the deficit due to fiscal stimulus is often responded to by increasing public debt. However, there is evidence that an increase in debt is not necessarily related to a deficit. Debt is the main tool used by various countries in obtaining funds in order to cover deficits. There is no consensus on the impact of debt on the economy. Widening the deficit to finance the deficit is beneficial in the short term, but the deficit must be controlled primarily in the long term.

The literature gaps found in this study can be used as a direction for future research, including:

a) Utilization of mixed methods in research related to the fiscal policy during the economic crisis

b) Expanding themes related to the influence of fiscal policy in the current crisis during the COVID-19 pandemic, expanding the theme to other public management themes such as human resources and the quality of public financial policies.

\section{REFERENCES}

Bal, D. B., \& Rath, B. N. (2016). Is public debt a burden for India?, Economic Papers, 3(2), 184-201?

Ban, C. (2015), Austerity versus Stimulus? Understanding Fiscal Policy Change at the International 
Vol.6, No.2, 2020

Doi: https://doi.org/10.24198/cosmogov.v6i2.29509

http://jurnal.unpad.ac.id/cosmogov/index

Monetary Fund Since the Great Recession, International Journal of Policy, Administration and Institutions, 28(2), 167-183.

Blanchard, O., \& Perotti, R. 2002, An empirical characterization of the dynamic effects of changes in government spending and taxes on output, Quarterly Journal of Economics, 117,1329-168

Beckman, Tristin. (2018), Reversing course: Fiscal policy and economic Interdependence, International Interactions, 44 (2), 361-384.

Blömer, M., Dolls, M., Fuest, C., Loffler, M., \& Peichl, A. German Public Finances through Financial Crisis. (2015), Discussion Paper No. 15041,1-23.

Brondolo, J. (2009), Collecting taxes during the economic crisis: Challenges and Policy Options, IMF Staff Position Note, International Monetary Fund.

Das, S. (2015), Growing Informality, Gender Equality and the Role of Fiscal Policy in the Face of the Current Economic Crisis: Evidence from the Indian Economy, International Journal of Political Economy, 44,277-295.

Deskar-Škrbić, M \& Simović, H. (2017), The effectiveness of fiscal spending in Croatia, Slovenia and Serbia: the role of trade openness and public debt level, Post-Communist Economies, 29(3), 336-358, https://doi.org/10.1080/14631377.2 016.1267972

Doraisami, A. (2014), Macro-Economic Policy Responses to Financial Crisis in Malaysia, Indonesia, and Thailand, Journal of Contemporary Asia, 44 (4), 591-598.

Essl, S., Celik, S.K, Kirby, P., Proite, A. (2019), Debt in low-income countries: Evolution, Implications, and remedies, Policy Research Working Paper 8794, World Bank Group.

Freedman, C., Kumhof, M., Laxton, D., \& Lee, Jaewoo. (2009), The case for global fiscal stimulus, IMF paper prepared by the Research Department.

Georgia Kaplanoglou and Vassilis $\mathrm{T}$. Rapanos. (2011), The Greek fiscal crisis and the role of fiscal governance. Hellenic Observatory Papers on Greece and Southeast Europe, Greece Paper No 48, 56.

Gravelle, J.G., Hungerford, T.L., Labonte, M. (2009), Economic Stimulus: Issues and Policies, Congressional Research Service.

Hur, Seok-Kyun \& Park, Donghyun. (2018), Did fiscal stimulus lift developing Asia out of the global crisis? An empirical investigation, East Asian Economic Review, 22(1), (March 2018).

Holland, M. (2019), Fiscal crisis in Brazil: causes and remedy, Brazilian Journal of Political Economy, 39 (1), 88-107, January-March/2019.

Kementerian Keuangan, 2020, Dampak COVID-19, Respon dan arah kebijakan fiskal, presentasi Kepala Pusat Kebijakan Ekonomi Makro Badan Kebijakan Fiskal Kementerian Keuangan pada FGD Pejabat Administrator Kebijakan Defisit Anggaran Pemerintah 30 Juli 2020.

Koh, W.C; Kose, M. A, Nagle, P, S., Ohnsorge, F, L., Sugawara, N. (2020). Debt and financial crisis, Policy Research Working Paper, World Bank Group.

Lee, Y, Ree, C., Sung, T. (2006), Fiscal policy in Korea: Before and after the financial crisis, International Tax and Public Finance, 13(4), 509-531.

Marglin, S.A., \& Spiegler, P. (2013), Unpacking the Multiplier: Making sense of Recent Assessment of Fiscal Stimulus Policy, Social Research, 80 (3), Fall 2013, 819854.

Mencinger, J \& Aristovnik, A. (2014), Fiscal policy stance reaction to the financial/economic crisis in the EMU: The Case of Slovenia, Zagreb International Review of 
Vol.6, No.2, 2020

Doi: https://doi.org/10.24198/cosmogov.v6i2.29509

http://jurnal.unpad.ac.id/cosmogov/index

Economics \& Business, 17, 616633.

Obstfeld M, Cho D, Mason A. Global Economic Crisis. Cheltenham: Edward Elgar Publishing. (, 2012). http://e-

resources.perpusnas.go.id:2076/log in.aspx?direct=true $\& \mathrm{db}=$ nlebk\&A $\mathrm{N}=470491 \&$ site $=$ eds-live.

Accessed July 26, 2020.

Padoan, P.C. (2009), Fiscal policy in the crisis: Impact, sustainability, and long-term implications, $A D B I$ Working Paper Series, No. 178 December 2009.

Përmeti, E. (2017). The role of public debt on economic growth, the case of Albania, Conference Paper, The $12^{\text {th }}$ edition of the International Conference European Integration Realities and Perspectives., 275279.

Peters, B. G., Pierre, J \& Randma-Liiv, T. (2011). The global financial crisis, public administration, and governance: Do new problems require new solutions? Public Organization Review, 11(1), 13-27.

Raudla, R. (2013), Fiscal retrenchment in Estonia during the financial crisis: The role of institutional factors, Public Administration, 91 (1), 3250.

Ramdhani, A., Rmadhani, M. A, Amin, A.S. (2014), Writing a literature review research paper: A Step by step approach, International of Journal of Basics and Applied Sciences, 3 (1), 47-56.
Romer, C. (2012), Fiscal Policy in the Crisis: Lessons and Policy Implications, Paper, University of California, Berkeley.

Rowley, J \& Slack, F. (2004), Conducting a literature review, Management Research News, 27(6), 31-39.

Simorangkir, I \& Adamanti, J. (2010), The role of fiscal stimulus and monetary easing in Indonesian economy during the global financial crisis: Financial computable general equilibrium approach, Bulletin of Monetary, Economics and Banking, October, 165-186.

Stupak, J. M. (2019). Fiscal policy: economic effects. Congressional Research Service, Report, 1-11.

Socol, A.G \& Feraru, R, M. (2017), The role of fiscal policy in the financial crisis: Challenges and solutions, Theoretical and Applied Economics, Vo. XXIV, No. 2, 5-20.

Van Riet, A. (ed.) (2010), Euro area fiscal policies and the crisis, Occasional Paper Series, No. 109, European Central Bank.

Zsolt, D (2009), The impact of the crisis on budget policy in Central and Eastern Europe, Bruegel Working Paper, No. 2009/05, Bruegel, Brussels. 